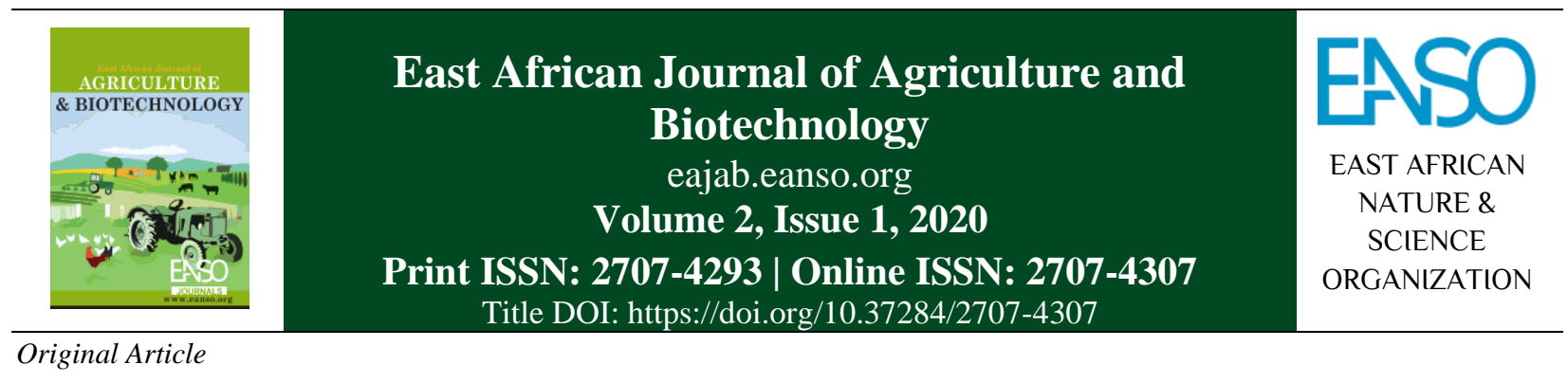

\title{
Identification of Blast Resistant Genotypes among Drought Tolerant Finger Millet in Uganda
}

\author{
John Charles Aru ${ }^{1 *}$, Nelson Wanyera ${ }^{1} \&$ Patrick Okori $^{2}$ \& Paul Gibson ${ }^{2}$ \\ ${ }^{1}$ National Semi-Arid Resources Research Institute, P. O. Box 56, Soroti, Uganda. \\ ${ }^{2}$ College of Agriculture and Environmental Sciences, Makerere University, P. O. Box 7062, Kampala. \\ * ORCID: https://orcid.org/0000-0003-4947-957X \\ *Author for Correspondence email: arucharles40@yahoo.com
}

Article DOI: https://doi.org/10.37284/eajab.2.1.235

\section{Date Published: ABSTRACT}

03 November 2020 Finger millet is an important food security crop among many subsistence farmers living in marginal and especially semi-arid Keywords: regions of Eastern Africa. However, crop production is affected mainly by terminal drought and blast disease caused by fungus

Blast, Pyricularia grisea. Both collectively lead to over $90 \%$ grain yield Blast Resistant Genotypes, Finger Millet, Drought Tolerance, Broad-Spectrum Resistance, Adapted Germplasm. loss depending on environmental conditions, cropping systems and varietal differences. Therefore, resistance breakdown remains high owing to variability in the blast pathogen and weather conditions. Stable varieties should possess both blast resistance and drought. In order to initiate breeding for multiple resistance to blast on drought-tolerant background, a study was conducted to identify variability for blast resistance from adapted germplasm as an initial step in developing a breeding strategy for incorporating resistance. Thirty genotypes from drought-prone agro-ecologies and including mini core germplasm from NARO-NaSARRI national Finger Millet improvement programme were assessed. They were screened using a local virulent pathogen isolate $\left(\mathrm{NGR}_{1}\right)$ from Ngora, representing Teso major farming system and is a hot spot for the blast. The screening was under controlled conditions from in Makerere University Agricultural Research Institute (MUARIK) in 2012b. The results showed significance $(\mathrm{p}<0.01)$ for Area Under Disease Progressive Curve (AUDPC). Subsequently, the study identified IE927, Seremi1, Seremi3, Sec220 and Kabale as highly resistant to foliar blast infection comparable to Gulu-E a standard broad-spectrum resistant check and they could be used to 
improve finger millet for blast resistance. Meanwhile DR33, IE9 and IE2576 as most susceptible compared to non-race -specific susceptible check E11 from Uganda.

\section{APA CITATION}

Aru, J., Wanyera, N., Okori, P., \& Gibson, P. (2020). Identification of Blast Resistant Genotypes among Drought Tolerant Finger Millet in Uganda. East African Journal of Agriculture and Biotechnology, 2(1), 58-70. https://doi.org/10.37284/eajab.2.1.235

\section{CHICAGO CITATION}

Aru, John, Nelson Wanyera, Patrick Okori, and Paul Gibson. 2020. "Identification of Blast Resistant Genotypes among Drought Tolerant Finger Millet in Uganda". East African Journal of Agriculture and Biotechnology 2 (1), 58-70. https://doi.org/10.37284/eajab.2.1.235.

\section{HARVARD CITATION}

Aru, J., Wanyera, N., Okori, P. and Gibson, P. (2020) "Identification of Blast Resistant Genotypes among Drought Tolerant Finger Millet in Uganda", East African Journal of Agriculture and Biotechnology, 2(1), pp. 58-70. doi: 10.37284/eajab.2.1.235.

\section{IEEE CITATION}

J. Aru, N. Wanyera, P. Okori, and P. Gibson, "Identification of Blast Resistant Genotypes among Drought Tolerant Finger Millet in Uganda", EAJAB, vol. 2, no. 1, pp. 58-70, Nov. 2020.

\section{MLA CITATION}

Aru, John, Nelson Wanyera, Patrick Okori, and Paul Gibson. "Identification of Blast Resistant Genotypes among Drought Tolerant Finger Millet in Uganda". East African Journal of Agriculture and Biotechnology, Vol. 2, no. 1, Nov. 2020, pp. 58-70, doi:10.37284/eajab.2.1.235.

\section{INTRODUCTION}

Finger millet also is known as Eleusine coracana (L.) Gaertn. Subspecies coracana belongs to the family Poaceae (Hilu et al., 1979). It is an important food security crop among many subsistence farmers living in marginal areas and especially in arid and semiarid regions of the world. The crop has food security and nutritional security, cultural, medicinal and economic value with high industrial potential. It represents the second most important cereal crop in Uganda after maize and is grown on an estimated annual area of 250,000 ha producing 277,000 metric tonnes (FAO DATA, 2018.) The development, release and adoption of improved varieties contribute largely to this production. The crop is mainly produced by small-scale farmers for direct consumption as a food and a cash crop. Out of the 277,000 Metric tonnes (Mt) of finger millet produced during the during 2008, the crop disposition was as follows: sold, 53,000 (19.0\%); consumed, 104,000 (37.7\%); stored, 93,000 (33.5\%); and used for other purposes, $27,000(9.8 \%)$. The grain has excellent storage capacity and recognised for health benefits such as anti-diabetic effects. However, the yield per acre in East Africa is continually declining at about $500 \mathrm{Kgs}$ per acre (AgStat,2016).

Most finger millet varieties are routinely challenged by the devastating blast disease, caused by the fungus Magnaporthe grisea, which results in up to $90 \%$ yield losses in combination with other abiotic stresses (Takan et al., 2012). Resistance instability remains high even among released varieties owing to specific reaction of the fungus strains to resistance conferred by mostly single genes leading to a breakdown of vertical resistance. Blast is mainly transmitted by air-borne 
conidia, through overwintering in plant debris and weed plants in the surrounding fields. More than 50 other Magnaporthe hosts are known, including cultivated grass species and weed species (Mackill \& Bonman, 1986). Virulence spectrum of the pathogen is associated with genetic diversity in Magnaporthe oryzae (Takan et al., 2012). Therefore, deployment of host plant resistance without aware of pathogen variation within pathogen populations results in crop failure and could make it very difficult to select for horizontal resistance. However, limited information on response to blast among mini core finger millet germplasm selected for drought tolerance with good breeding potential. Therefore, the objective of the study was to identify sources of resistance that could be introgressed into susceptible preferred droughttolerant backgrounds. This information will support breeding for multiple resistance which enhances plant fitness, thus contributing to high yielding resilient varieties.

\section{MATERIALS AND METHODS}

\section{Survey}

A survey was carried out using nonrepresentative sampling in three districts of eastern Uganda to study disease prevalence in major finger millet growing areas during the second rains (2011b), on the basis of previous work (Adipala \& Wandera, 2001). Ten infected plant parts were collected from Kachumbala in fields mapped with GP with co-ordinates 36.623028E, 01.36489N at about 1172 metres above sea level. For Tororo district, ten samples were collected from Magola subcounty in fields located at GPS 36.618007E, $00.65710 \mathrm{~N}$ at an altitude of 1092 metres above sea level. The above sites are distinct agroecologies around the slopes of Mount Elgon, representing cool and wet areas where the most aggressive pathogen isolates were obtained on the basis of previous work (Adipala \& Wandera, 2001). The third site was Ngora district that represents hotter environments, and ten samples were picked from Odwarat subcounty $36.587968 \mathrm{E}, 0161645 \mathrm{~N}$ at 1106 metres above sea level. Disease severity was on average $30-50 \%$ measured on two-point scale 1 $=$ Slight infection (Auxiliary leaves), $2=$ moderate to severe infection (of green panicle or severe leaf symptoms). Disease reaction was given in terms of disease index (DI), where

$$
D I=\frac{\text { (Incidence } x \text { Average severity) }}{2} .
$$

Table 1: List of drought-tolerant genotypes for artificial screening against Pyricularia

\begin{tabular}{lllll}
\hline & Genotype & Pedigree & Origin & Description under natural infection \\
\hline 1 & Pese 1 & P224 & Com. Variety & Resistant to head blast \\
2 & Seremi 1 & P249 & Com. Variety & Resistant to foliar and head blast \\
3 & Seremi 2 & U 15 & Com. Variety & Susceptible to foliar blast \\
4 & Seremi 3 & S x17-88 & Com. Variety & Resistant to head and leaf blast \\
5 & Serere 14 & Serere 14 & Breeder's stock & Resistant to head and leaf blast \\
6 & Sec 20 & Sec 20 & Breeder stock & Resistant to head blast \\
7 & Sec 21 & Sec 21 & Breeder's stock & Resistant to head and leaf blast \\
8 & Sec 97 & Sec 97 & Breeder's stock & Resistant to head and leaf blast \\
9 & Sec 220 & Sec 220 & Breeder stock & Resistant to head and leaf blast \\
10 & Sec 659 & Sec 659 & Breeder's stock & Resistant to head and leaf blast \\
11 & DR 21 & DR 21 & Malawi & Resistant to leaf blast \\
12 & DR 32 & DR 32 & Malawi & Resistant to head blast
\end{tabular}


East African Journal of Agriculture and Biotechnology, Volume 2, Issue 1, 2020

Article DOI: https://doi.org/10.37284/eajab.2.1.235

\begin{tabular}{|c|c|c|c|c|}
\hline & Genotype & Pedigree & Origin & Description under natural infection \\
\hline 13 & DR 33 & DR 33 & Malawi & Resistant to head blast \\
\hline 14 & DR 8 & DR 8 & Malawi & Resistant to leaf blast \\
\hline 15 & DR 62 & DR 62 & Malawi & Resistant to leaf blast \\
\hline 16 & DR 43 & DR 43 & Malawi & Resistant to foliar and head blast \\
\hline 17 & E11 & E11 & Uganda & $\begin{array}{l}\text { Susceptible to all forms of blast (Susceptible } \\
\text { check) }\end{array}$ \\
\hline 18 & KAT FM1 & KAT FM1 & Kenya & Susceptible to foliar blast \\
\hline 19 & Gulu-E & Gulu-E & Landrace & Resistant check to all forms \\
\hline 20 & Engeny & Engeny & Landrace & Resistant to head blast head \\
\hline 21 & Kabale & Kabale & Landrace & Resistant to head blast \\
\hline 22 & Emiroit & Emiroit & Landrace & Resistant to head blast \\
\hline 23 & Okiring & Okiring & Landrace & Resistant to head blast \\
\hline 24 & IE 4545 & IE 4545 & India eleusine & Resistant to leaf blast \\
\hline 25 & IE 927 & IE 927 & India eleusine & Resistant to head blast \\
\hline 26 & I.E. 9 & I.E. 9 & India eleusine & Resistant to leaf blast \\
\hline 27 & IE775 & IE775 & India eleusine & Resistant to head blast \\
\hline 28 & IE 2540 & IE 2540 & India eleusine & Resistant to leaf blast \\
\hline 29 & IE2790 & IE2790 & India eleusine & Resistant to head blast \\
\hline 30 & IE2756 & IE2756 & India eleusine & Resistant to leaf blast \\
\hline
\end{tabular}

Source: (NaSARRI, 2012). Com. = Commercial variety

Preparation of Monoconidial Cultures and Layout of Experiments

(a) For isolate screening, the experiment was laid in a split-plot design with three pure isolates as subplots and standard finger millet resistant variety (Gulu-E) and susceptible variety (E11) as main plots. The experiment was conducted under the screen house from Makerere University Agricultural Research Institute Kabanyolo (MUARIK). Each pot had five plants and replicated three times, where data was collected from each plant and averaged per pot. The two varieties were deployed on the subplots (three isolates). Samples of infected plant plants (leaf, neck and head) were surface sterilized at $1 \%$ solution of sodium hypochlorite and rinsed in sterile distilled water for two minutes and then planted in $9 \mathrm{~cm}$ pyrex Petric dish. All standard protocol for pathogen isolation, inoculum preparation, adjustment of the concentration of spore suspension to 100,000 spores per $\mathrm{ml}$ and inoculation was according to (David et al., 2008). The plants were inoculated at 35 days after sowing, which was at 4-5 leaf stage (Ghazanfar, Habib \& Sahi, 2009). High humidity was maintained by means of a polythene bag to facilitate infection and to prevent the spray from a particular isolate drifting to other blocks

(b) For screening of germplasm for reaction to blast, the pots were filled with a mixer of soil and farm-yard manure at a ratio of 3:1 and wellwatered. Thirty pots made up one replication of 30 genotypes planted in 5x6 alpha lattices and replicated 3 times. One standard resistant check (Gulu-E) and one susceptible check $\left(\mathrm{E}_{11}\right)$ were included in all the experiments as controls. The plants were inoculated by spraying using most virulent pathogen isolate identified from isolate screening. High humidity was maintained by means of a polythene bag to facilitate infection. The plants were inoculated at 35 days after sowing, which was at 4-5 leaf stage and booting stage (55 days) for the case of head and neck blast (Ghazanfar, Habib \& Sahi, 2009). The 
main parameters measured were leaf, neck and head infection.

\section{Data Collection Based on Lesion Size, Percentage Leaf Area Affected and Head Blast Infection}

Disease severity was recorded in terms of lesion size and percentage leaf area infected at two weeks interval from five days after inoculation up to physiological maturity (110 days) using 1-5 quantitative scale modified from (Ghazanfar, Habib \& Sahi, 2009). For head blast infection severity ratings based on the number of fingers affected from grain filling stage up to harvest maturity. For the case of neck blast, sizes of lesions estimated from grain filling to harvest maturity using a similar scale based on the number of lesions on the neck. The disease intensity data based on lesion size was later transferred to the area under the progressive disease curve (AUDPC). The AUDPC is average infection across time, which gives you an impression and amounts to overall stress. The entries were later grouped as highly resistant, moderately resistant, moderately susceptible and susceptible on the basis of standardized $\mathrm{z}$-scores of areas under disease progress curves (McLeod, S. A. 2019). A negative $\mathrm{z}$-score reveals the raw score is below the mean average and denotes resistance. The relative area under disease progressive curves or disease rating index is to quantify disease intensity over time (Mohapatra et al., 2009).

Table 2: Disease rating (1-5) scale for leaf blast lesion types caused by $P$. grisea

\begin{tabular}{lll}
\hline 1 & Highly resistant & No symptoms or brown specks $<0.5 \mathrm{~mm}$ in diameter. \\
\hline 2 & Resistant & Slightly larger brown specks $2-3 \mathrm{~mm}$ in diameter. \\
\hline 3 & Moderately & $\begin{array}{l}\text { Round to elliptical lesions restricted up to } 3 \mathrm{~mm} \text { in diameter with necrotic } \\
\text { grey centre }\end{array}$ \\
\hline 4 & $\begin{array}{l}\text { Mosistant } \\
\text { susceptible }\end{array}$ & $\begin{array}{l}\text { Typical elliptical-shaped blast lesion restricted up to } 6 \mathrm{~mm} \text { long with the } \\
\text { little coalescence of veins and yellow margin. }\end{array}$ \\
\hline 5 & Susceptible & $\begin{array}{l}\text { Half or more of the leaf-covered by coalescence of large lesions more } \\
\text { than } 6 \mathrm{~cm}, \text { yellowing of leaves and leaves may be killed by coalescence } \\
\text { of large lesions. }\end{array}$ \\
& &
\end{tabular}

Modified from Ghazanfar, Habib \& Sahi (2009)

Generally, plants rated 1-3 were considered resistant, while those rated 4-5 considered susceptible (Table 2 and 3). Resistance was expressed by restricting the amount of tissue that is colonized at a single infection site or slow propagation of the virulent pathogen. The score data was used for computing percentage disease incidence (PDI) with the formula:

$$
P D I=\left[\frac{\text { Sum of numerical rating }}{\text { Total number of leaves observed }} x \text { Maximum score }\right] x 100 .
$$


East African Journal of Agriculture and Biotechnology, Volume 2, Issue 1, 2020

Article DOI: https://doi.org/10.37284/eajab.2.1.235

Highly susceptible plant genotype with above $40 \%$ disease severity. (Islam et al., 2018)

Table 3: Disease severity ratings for leaf blast

\begin{tabular}{lll}
\hline Severity & Per cent Severity & Host response \\
\hline $1.0-1.4$ & $0-5 \%$ of leaf area & HR \\
$1.5-1.9$ & $6-10 \%, \quad$ & $\mathrm{R}$ \\
$2.0-2.4$ & $11-20 \%$, & $\mathrm{MR}$ \\
$2.5-2.9$ & $21-30 \%$, & $\mathrm{S}$ \\
$3.0-3.5$ & $31-40 \%$, & $\mathrm{HS}$ \\
$3.6-5.0$ & $>40 \%,$, & $\mathrm{ES}$ \\
\hline
\end{tabular}

HR=highly resistant; $S=$ Susceptible; $H S=$ highly susceptible; $E S=$ extremely susceptible; $R=$ Resistant; $M R=$ moderately resistant. Scale was modified from (Ghazanfar, Habib \& Sahi, 2009) 3.2.5 Data Analysis

The area under the disease progress curve (AUDPC) was computed using the formula from (Campbell \& Maidden., 1990). The disease scores were standardized (Z-scores) by dividing with the number of days to the last assessment time, where Z-score less than zero is resistant (AUDPC-grand mean)/standard deviation. The relative area under disease progressive curve (RAUDPC), which is the proportion of the leaf area affected from a given genotype compared to the most susceptible variety, computed as $\boldsymbol{A U D P C}=\boldsymbol{\Sigma}$ $\left.\left[\mathbf{y}_{1}+\mathbf{y}_{1}+1\right) / 2\right]\left(t_{1}+1-t_{1}\right)$, where " $t$ " is time in days of each evaluation (evaluation was at the interval of two weeks after infection and was accumulated for 56 days with four data sets. "Y" is the disease score for the affected leaf. AUDPC was subjected to analysis of variance (ANOVA) and analysed quantitatively as the relative area under disease progressive curve (rAUDPC). Correlations of patterns of disease response from the leaf, neck and the head were done using with the most resistant receiving higher ranking when the data was sorted. The repeated rank test was used when two or more genotypes tied a place in ranking as according to in order to make an adjustment to the original spearman's ranked correlation (Veerachamy, 2008). Correlations of the pattern of disease responses from leaf, neck and head were done using a coefficient of correlation ' $r$ '" where $r>0$ indicates increases of relatedness.

\section{RESULTS}

Virulent Pathogen Isolate Identified for Screening Germplasm

Analysis of variance revealed significant effects ( $p<0.05$ ) of isolates on standard checks Gulu-E and E11 (Table 4). The Ngora isolate $\left(\mathrm{NGR}_{1}\right)$ formed the longest lesions, therefore considered most aggressive, followed by Kachumbala $\left(\mathrm{KAC}_{1}\right)$. Overall ranking indicated that the isolates obtained from three hot spots from eastern agro-ecologies of Uganda showed variation in virulence. 
Table 4: Identification of the most virulent pathogen isolates to be used for screening

\begin{tabular}{ll}
\hline Isolate & $\begin{array}{l}\text { Mean } \\
\text { infection }\end{array}$ \\
\hline Tororo $\left(\mathrm{TRO}_{1}\right)$ & $1.75 \mathrm{a}$ \\
Kachumbala $\left(\mathrm{KAC}_{1}\right)$ & $2.28 \mathrm{~b}$ \\
Ngora $\left(\mathrm{NGR}_{1}\right)$ & $2.67 \mathrm{c}$ \\
S.E. $\mathrm{D}$ & 0.15 \\
$\mathrm{LSD}$ & 0.32 \\
$\mathrm{C} . \mathrm{V}$ & $11.4 \%$ \\
\hline$a=; b=; c=$ Mean infection followed by \\
different letter is significantly different at \\
$\alpha=0.05$
\end{tabular}

Differences Among Germplasm for Reaction to Leaf Blast Reaction

Analysis of variance on each form of the blast was significant $(\mathrm{p}<0.05)$ (Table 5). On the basis of standardized disease scores, accumulated AUDPC and RAUDPC; genotypes Seremi1, Seremi3, Sec659, Sec220, Kabale and Gulu-E were classified as highly resistant. Meanwhile E11, IE 4545, DR33 and Okiring were found to be being highly susceptible, because they had highest positive z- score of AUDPC above 2 and RAUDPC above 0.60 compared to standard susceptible check E11.

Table 5: Z- Scores for 30 genotypes of finger millet screened for resistance

\begin{tabular}{lllll}
\hline Genotype & AUDPC & Z-score & Reaction & RAUDPC (56 days) \\
\hline DR21 & 120.1 & 0.3 & MR & 0.57 \\
DR32 & 117.1 & -0.1 & $\mathrm{R}$ & 0.56 \\
DR33 & 142.4 & 3.5 & HS & 0.68 \\
DR43 & 116.5 & -0.2 & $\mathrm{R}$ & 0.55 \\
DR62 & 119.9 & 0.2 & MR & 0.57 \\
DR8 & 119 & 0.2 & MR & 0.57 \\
E11(susceptible) & 142.7 & 3.5 & HS & 0.68 \\
EGENY & 120.9 & 0.4 & MR & 0.58 \\
EMIROIT & 135.4 & 2.5 & HS & 0.64 \\
GULU-E (resistant check) & 103 & -2.1 & HR & 0.49 \\
IE2540 & 119.9 & 0.2 & MR & 0.57 \\
IE2756 & 124.4 & 0.9 & MR & 0.59 \\
IE2790 & 142.6 & 3.5 & HS & 0.68 \\
IE4545 & 116.5 & -0.2 & R & 0.61 \\
IE775 & 135.7 & 2.5 & HS & 0.65 \\
IE9 & 125.7 & 1.1 & S & 0.63 \\
IE927 & -3.9 & HR & 0.42 \\
KABALE & -2.6 & HR & 0.48 \\
KATFM1 & 90.3 & 3.5 & HS & 0.67 \\
OKIRING & 99.8 & 2.3 & HS & 0.64 \\
PESE1 & 142.4 & -0.5 & R & 0.55 \\
SEC20 & 133.8 & -2.0 & HR & 0.51 \\
SEC21 & 114.5 & 0.1 & MR & 0.57 \\
SEC220 & 104.2 & HR & 0.53 \\
& 118.7 & & &
\end{tabular}


East African Journal of Agriculture and Biotechnology, Volume 2, Issue 1, 2020

Article DOI: https://doi.org/10.37284/eajab.2.1.235

\begin{tabular}{lllll}
\hline Genotype & AUDPC & Z-score & Reaction & RAUDPC (56 days) \\
\hline SEC659 & 111 & -1.0 & $\mathrm{HR}$ & 0.54 \\
SEC97 & 114.1 & -0.5 & $\mathrm{R}$ & 0.54 \\
SEREMI1 & 99.4 & -2.6 & $\mathrm{HR}$ & 0.47 \\
SEREMI2 & 129.5 & 1.7 & $\mathrm{~S}$ & 0.62 \\
SEREMI3 & 99.3 & -2.7 & $\mathrm{HR}$ & 0.50 \\
SERERE14 & 108.9 & -1.3 & $\mathrm{HR}$ & 0.54 \\
\hline Grand Mean AUDPC & 117.9 & & & \\
CV \% & 10.3 & & & \\
LSD $(\mathrm{P}<0.001)$ & 19.9 & & & \\
\hline
\end{tabular}

Disease Reaction at Physiological Maturity

Disease responses varied from seedling through the vegetative stage up to physiological maturity (Table 6). About $20 \%$ of the genotypes screened maintained resistant reaction to all forms blast with mean score of 33.0. Other studies have reported that resistance to leaf blast is conferred by the presence of Silicon. Such genotypes, therefore, show adaptive phenotypic expression and offer prospects for breeding blast resistance. There could be structural, biochemical, genetic or molecular interaction of the host and the pathogen that is important in the management of blast disease, that need to be identified and incorporated into breeding populations to improve efficiency in selection.

Table 6: Final Mean Blast Severity Scores at Physiological Maturity

\begin{tabular}{lllll}
\hline Entry & Genotype & Leaf & Neck & Head \\
\hline 1 & DR21 & 3.6 & 4 & 3.6 \\
2 & DR32 & 3.7 & 2.9 & 3.5 \\
3 & DR33 & 4 & 3.4 & 3.9 \\
4 & DR43 & 2.7 & 3.1 & 2.7 \\
5 & DR62 & 2.8 & 2.4 & 2.4 \\
6 & DR8 & 3.8 & 3 & 3.3 \\
7 & IE2540 & 3.4 & 3 & 2.9 \\
8 & IE2756 & 3.6 & 3 & 3.6 \\
9 & IE2790 & 4.2 & 3.3 & 3.9 \\
10 & IE4545 & 2.2 & 2.4 & 3.1 \\
11 & IE775 & 3.3 & 2.8 & 3 \\
12 & IE9 & 3.6 & 3.3 & 4.1 \\
13 & IE927 & 2.3 & 2.9 & 3.1 \\
14 & EGENY & 2.9 & 2.4 & 3.2 \\
15 & EMIROIT & 3.4 & 3.6 & 3.7 \\
16 & KABALE & 3 & 2.5 & 2.7 \\
17 & OKIRING & 3.4 & 2.7 & 3 \\
18 & SEC20 & 2.9 & 2.8 & 2.9
\end{tabular}


East African Journal of Agriculture and Biotechnology, Volume 2, Issue 1, 2020

Article DOI: https://doi.org/10.37284/eajab.2.1.235

\begin{tabular}{lllll}
\hline Entry & Genotype & Leaf & Neck & Head \\
\hline 19 & SEC21 & 2.7 & 3 & 2.9 \\
20 & SEC220 & 2.8 & 1.9 & 2.1 \\
21 & SEC659 & 4 & 3.2 & 3.2 \\
22 & SEC97 & 2.4 & 2 & 2.8 \\
23 & SEREMI1 & 2.7 & 2.1 & 1.9 \\
24 & SEREMI2 & 3.7 & 3.4 & 3.3 \\
25 & SEREMI3 & 2.9 & 2.1 & 2.3 \\
26 & SERERE14 & 2.7 & 2.8 & 2.9 \\
27 & PESE1 & 2.7 & 3 & 2.8 \\
28 & SERERE1 & 2.7 & 2.8 & 2.9 \\
29 & GULU-E (R-check) & 2.4 & 1.7 & 1.9 \\
30 & E11 (S-Check) & 3.9 & 3.6 & 3.8 \\
31 & KATFM (S-check) & 3.9 & 3.4 & 3.6 \\
\hline & LSD (0.01) & 1.06 & 0.98 & 0.74 \\
& C.V & 18 & 19.6 & 18.9 \\
& S.E. D & 0,63 & 0.38 & 0.34 \\
\hline
\end{tabular}

When mean disease responses were ranked; Gulu-E, Kabale and Sec220 were consistent in maintaining the highest ranking for the three forms of the blast (Table 7). Testing the significance of lack of good fit through regression of leaf blast on neck blast gave observed $\mathrm{t}=3.84>2.048$ tabulated value, at $\alpha=$ 0.05 was not significant. Meanwhile, correlation of leaf blast on head blast gave observed $\mathrm{t}=5.29>3.84$ was significant. However, coefficients of determination $\left(\mathrm{R}^{2}\right)$ were generally not above $50 \%$.

Table 7: Repeated Ranks for Testing Significance of Ranked Correlations Between Forms of the blast

\begin{tabular}{|c|c|c|c|c|c|c|c|c|c|}
\hline Genotype & $\begin{array}{l}\text { Leaf blast } \\
\text { Rank } \\
\text { (RL) }\end{array}$ & $\begin{array}{l}\text { Neck blast } \\
\text { Rank } \\
(\text { RN) } \\
\end{array}$ & $\begin{array}{l}\text { Head blast } \\
\text { Rank } \\
\text { (RH) } \\
\end{array}$ & $\begin{array}{l}\mathbf{D}_{1} \\
\text { (RL- } \\
\text { RN) }\end{array}$ & $D^{2}{ }_{1}$ & $\begin{array}{l}\mathbf{D}_{2} \\
\text { (RL- } \\
\text { RH) }\end{array}$ & $\mathrm{D}^{2}{ }_{2}$ & $\begin{array}{l}\text { D3 } \\
\text { (RN } \\
- \\
\mathbf{R H}) \\
\end{array}$ & $\mathrm{D}^{2}{ }_{3}$ \\
\hline DR21 & 10 & 25 & 21.5 & -15 & 225 & -11.5 & 132.3 & 3.5 & 12.25 \\
\hline DR32 & 10 & 9.5 & 14 & 0.5 & 0.25 & -4 & 16 & -4.5 & 20.25 \\
\hline DR33 & 22.5 & 28 & 28 & -5.5 & 30.25 & -5.5 & 30.25 & 0 & 0 \\
\hline DR43 & 16.5 & 26 & 17 & -9.5 & 90.25 & -0.5 & 0.25 & 9 & 81 \\
\hline DR62 & 19 & 17 & 12.5 & 2 & 4 & 6.5 & 42.25 & 4.5 & 20.25 \\
\hline DR8 & 10 & 22.5 & 19.5 & -12.5 & 156.25 & -9.5 & 90.25 & 3 & 9 \\
\hline E11 & 24 & 30 & 30 & -6 & 36 & -6 & 36 & 0 & 0 \\
\hline EGENY & 19 & 22.5 & 9 & -3.5 & 12.25 & 10 & 100 & 13.5 & 182.3 \\
\hline EMIROIT & 24 & 19.5 & 25 & 4.5 & 20.25 & -1 & 1 & -5.5 & 30.25 \\
\hline
\end{tabular}




\begin{tabular}{|c|c|c|c|c|c|c|c|c|c|}
\hline Genotype & $\begin{array}{l}\text { Rank } \\
\text { (RL) }\end{array}$ & $\begin{array}{l}\text { Rank } \\
\text { (RN) }\end{array}$ & $\begin{array}{l}\text { Rank } \\
(\mathbf{R H})\end{array}$ & $\begin{array}{l}\text { (RL- } \\
\text { RN) }\end{array}$ & $\mathrm{D}^{2}{ }_{1}$ & $\begin{array}{l}\mathbf{D}_{2} \\
\text { (RL- } \\
\text { RH) }\end{array}$ & $\mathrm{D}^{2}{ }_{2}$ & $\begin{array}{l}\text { D } \\
(\mathbf{R N} \\
- \\
\text { RH) } \\
\end{array}$ & $\mathrm{D}^{2}{ }_{3}$ \\
\hline GULU-E & 1 & 4 & 2 & -3 & 9 & -1 & 1 & 2 & 4 \\
\hline IE2540 & 16.5 & 5.5 & 9 & 11 & 121 & 7.5 & 56.25 & -3.5 & 12.25 \\
\hline IE2756 & 18 & 29 & 19.5 & -11 & 121 & -1.5 & 2.25 & 9.5 & 90.25 \\
\hline IE2790 & 24 & 17 & 25 & 7 & 49 & -1 & 1 & -8 & 64 \\
\hline IE4545 & 19 & 14.5 & 25 & 4.5 & 20.25 & -6 & 36 & -10.5 & 110.3 \\
\hline IE775 & 20.5 & 22.5 & 25 & -2 & 4 & -4.5 & 20.25 & -2.5 & 6.25 \\
\hline IE9 & 20 & 14.5 & 29 & 5.5 & 30.25 & -9 & 81 & -14.5 & 210.3 \\
\hline IE927 & 6.5 & 19.5 & 17 & -13 & 169 & -10.5 & 110.3 & 2.5 & 6.25 \\
\hline KABALE & 4 & 5.5 & 2 & -1.5 & 2.25 & 2 & 4 & 3.5 & 12.25 \\
\hline KATFM1 & 22.5 & 27 & 25 & -4.5 & 20.25 & -2.5 & 6.25 & 2 & 4 \\
\hline OKIRING & 19 & 9.5 & 15 & 9.5 & 90.25 & 4 & 16 & -5.5 & 30.25 \\
\hline PESE1 & 14 & 22.5 & 9 & -8.5 & 72.25 & 5 & 25 & 13.5 & 182.3 \\
\hline SEC20 & 2 & 9.5 & 9 & -7.5 & 56.25 & -7 & 49 & 0.5 & 0.25 \\
\hline SEC21 & 14 & 12.5 & 9 & 1.5 & 2.25 & 5 & 25 & 3.5 & 12.25 \\
\hline SEC220 & 2 & 1 & 2 & 1 & 1 & 0 & 0 & -1 & 1 \\
\hline SEC659 & 8.5 & 12.5 & 17 & -4 & 16 & -8.5 & 72.25 & -4.5 & 20.25 \\
\hline SEC97 & 6.5 & 9.5 & 21.5 & -3 & 9 & -15 & 225 & -12 & 144 \\
\hline SEREMI1 & 8.5 & 3 & 4.5 & 5.5 & 30.25 & 4 & 16 & -1.5 & 2.25 \\
\hline SEREMI2 & 20.5 & 17 & 12.5 & 3.5 & 12.25 & 8 & 64 & 4.5 & 20.25 \\
\hline \multicolumn{10}{|l|}{ SERERE1 } \\
\hline 4 & 14 & 7 & 6 & 7 & 49 & 8 & 64 & 1 & 1 \\
\hline \multicolumn{10}{|c|}{ Original spear man's ranked correlation $P=1-6 \sum \mathrm{D}^{2} / \mathrm{n}\left(\mathrm{n}^{2}-1\right)$ where $\mathrm{D}=\mathrm{R}_{\mathrm{X}}-\mathrm{R}_{\mathrm{Y}}$} \\
\hline $\begin{array}{l}P=\text { is rank c } \\
\text { Correlation } \\
\text { Correlation } \\
\text { Correlation }\end{array}$ & rrelation coef & $\begin{array}{l}\text { icient and } \mathrm{D} \\
\text { ween leaf bla }\end{array}$ & is the differe & $\begin{array}{l}\text { ce betv } \\
\text { st is } \mathrm{P}=\end{array}$ & ranks. I & rank po & Ions & & \\
\hline
\end{tabular}

\section{DISCUSSION}

\section{Virulent Isolate Identification}

Isolates obtained from the three hot spots in different locations from eastern savannah agroecology of Uganda showed differences in virulence. A highly virulent isolate produced larger size of susceptible reaction types on plants in comparison to the less virulent isolates (Niangabo, 2010). He also observed variations in pathogenicity among isolates of the fungus from different locations. However, in this study isolates from Ngora representing warmer regions seemed more aggressive with faster lesion expansion rate. This is also supported by other studies, whereby the isolates from drier areas (Soroti in particular) had faster growth but low sporulation (Adipala \& Wandera, 2001). Similar findings were observed in Brazil on wheat grown under high temperature with rainfall of $15 \mathrm{~mm}$ according to 
(Urashima et al., (2009). From this study, germplasm should be screened using most aggressive pathogen populations. Hence, continuous survey and monitoring the existing virulences and pathogen races in the country is very important as a way of an early warning of the breakdown of specific resistant genes of the commercial varieties.

\section{The reaction of Germplasm to Infection}

Differences in varietal reaction to the blast were also reported in Uganda with finger millet variety Gulu-E having considerable resistance (Bua \& Adipala, 1995). Our results also confirm this resistance of Gulu-E to blast among genotypes screened with NGR $_{1}$ pathogen isolate. Genotypes could have differed because of the history of breeding and selection both artificially and naturally. Comparison of the reactions helped to classify finger millet germplasm into highly resistant, resistant, moderately resistant, susceptible and highly susceptible. This provides opportunities for further studies on causes of such differences and their genetic control. Disease reaction need not be of the highest order, but genotype should be able to maintain epidemic development at minimum up to grain filling stage in order to minimize yield losses. A resistant variety should able to withstand high inoculum with little disease development. They are characterized by reduced lesion size and restricted sporulation, hence prevent secondary spread during early infection cycles and such genotype should be recommended for deployment.

\section{Relationship between Forms of Blast}

There was a moderate relationship in the pattern of resistance to forms of the blast from the consistency in high ranking among resistant genotypes and low ranking among the susceptible genotypes. A low coefficient of determination suggests that one form of the blast cannot be strongly predicted from the other and hence reduces the power for indirect selection. This observation could be a result of co-founding factors not yet known which might be structural, physiological, molecular or genetic, which needs to be determined to be incorporated into breeding progenies. Similar results were obtained from Oduori (2008).

\section{CONCLUSION}

The study, whose aim was to identify sources genetic resistance for improving droughttolerant finger millet, was approached through identifying the most virulent pathogen isolate for screening thirty selected breeder's material. $\mathrm{NGR}_{1}$ pathogen isolate represents the most aggressive population that could be existing in the area. It is, therefore, the most desirable isolate for screening genotypes for broad resistance, however, whether the variability indicates the considerable presence of different biotypes (races) is still unclear since this was not studied on race identification. These need to be ascertained periodically since Pyricularia grisea is a highly variable pathogen with wide host range. Finger millet genotypes: IE927, Kabale, Gulu-E Seremil and Seremi 3 are resistantly expressed as a reduction in lesion number and relative area under disease progressive curve (RAUDPC). Meanwhile, Sec21 and DR21 are fairly resistant and E11, DR33 and IE2790 were categorized as are very susceptible because they registered the highest number of lesions. Morphological structures such as leaf and neck thickness and biochemical compounds such as levels tannin 
might need to be explored together with diversity for blast resistance among landrace varieties exploited.

\section{REFERENCES}

Adipala, E., \& Wandera., K. (2001). Variation in pathogenicity of Uganda finger millet Pyricularia grisea isolates. Africa Crop Science Conference Proceedings, 5, 369379

AgStat. (2016). SEPC, Dept of Agriculture. Available http//doa.govlk/FCRD/index.php/en/crops/ 45 finger millets.

Bua, B., \& Adipala, E. (1995). Relationship between head blast severity and yield of finger millet. International Journal of Pest Management, 41(1), 55-59.

Campbell, C. L., \& Madden, L. V. (1990). Introduction to plant disease epidemiology. John Wiley \& Sons.

FAO DATA,2018. On Finger millet production trends 2014 to 2018. Available at (http//Iwww:fao,org/faostat/en \#data)

Ghazanfar, M. U., Habib, A., \& Sahi, S. T. (2009). Screening of rice germplasm against Pyricularia oryzae the cause of rice blast disease. Pak. J. Phytopathol, 21(1), 41-44.

Hilu, K. W., De Wet, J. M. J., \& Harlan, J. R. (1979). Archaeobotanical studies of Eleusine coracana ssp. coracana (finger millet). American Journal of Botany, 66(3), 330-333.

Islam, R., Al Mamun, A., Alam, M. J., Anwar, M. B., \& Hakim, M. A. (2018). Yield
Performance and Blast Susceptibility of Some Wheat (Triticum aestivum) Varieties in Jashore. The Agriculturists, 16(02), 6574.

Mackill, A., \& Bonman, J. (1986). New hosts of Pyricularia oryzae. Plant Disease 70(2), 125-127.

McLeod, S. A. (2019, May 17). Z-score: definition, calculation and interpretation. Retrieved from https://www.simplypsychology.org/zscore. html

Mohapatra, N. K., Mukherjee, A. K., Suriya Rao, A. V., \& Nayak, P. (2008). Disease progress curves in the rice blast pathosystem compared with the logistic and Gompertz models. Journal of Agricultural and Biological Science, 3(1), 28-37.

NaSARRI., (2012). Agro-morphological characterization of finger millet germplasm in Serere for conserving genetic diversity. In NaSARRI annual report 2012.

Niangabo. V. (2010). Inheritance of Resistance to Blast in Rice. Msc. Thesis. Makerere university

Oduori, C. O. (2008). Breeding investigations of finger millet characteristics including blast disease and striga resistance in Western Kenya. (Doctoral dissertation). University of KwaZulu-Natal.

Parker, D., Beckmann, M., Enot, D. P., Overy, D. P., Rios, Z. C., Gilbert, M., ... \& Draper, J. (2008). Rice blast infection of Brachypodium distachyon as a model 
system to study dynamic host/pathogen interactions. Nature Protocols, 3(3), 435.

Silva, W. L. D., Cruz, M. F. A., Fortunato, A. A., \& Rodrigues, F. Á. (2015). Histochemical aspects of wheat resistance to leaf blast mediated by silicon. Scientia Agricola, 72(4), 322-327.

Takan, J. P., Chipili, J., Muthumeenakshi, S., Talbot, N. J., Manyasa, E. O., Bandyopadhyay, R., ... \& Brown, A. E. (2012). Magnaporthe oryzae populations adapted to finger millet and rice exhibit distinctive patterns of genetic diversity, sexuality and host interaction. Molecular biotechnology, 50(2), 145-158.

Urashima, A. S., Grosso, C., Stabili, A., Freitas, E., Silva, D., Franco, I. \& Bottan, M. (2009). Effect of Magnaporthe grisea on seed germination, yield and quality of wheat. In Wang, G. L. \& Valent, B. (Eds) Advances in genomics and control of rice blast (267-277). Netherlands: Springer.

Veerachamy, R. (2008). Quantitative Methods for Economists. New Age International. 